\title{
Author Correction: How Emotional Intelligence Promotes Leadership and Management Practices
}

\section{Christopher K. Gransberry ${ }^{1}$}

Published online: 22 September 2021

(C) Springer Science+Business Media, LLC, part of Springer Nature 2021

\section{Author Correction: Public Organization Review https://doi.org/10.1007/s11115-021-00550-4}

The original version of this article unfortunately contained a mistake in the copyright holder. The correct copyright holder is "The Author(s), under exclusive licence to Springer Science + Business Media, LLC, part of Springer Nature".

The original article has been corrected.

Publisher's Note Springer Nature remains neutral with regard to jurisdictional claims in published maps and institutional affiliations.

The original article can be found online at https://doi.org/10.1007/s11115-021-00550-4.

Christopher K. Gransberry

Ckgransberry@csmd.edu

1 College of Southern Maryland, 8730 Mitchell RoadLa Plata, PO Box 910, La Plata, MD 20646, USA 